\title{
Anthocyanins standards (cyanidin-3-O-glucoside and cyanidin-3-O-rutinoside) isolation from freeze-dried açaí (Euterpe oleraceae Mart.) by HPLC
}

\author{
Isolamento de padrões de antocianinas (cianidina-3-O-glucosídeo e cianidina-3-O-rutinosídeo) \\ de açaí liofilizado (Euterpe oleraceae Mart.) por CLAE
}

\author{
Ana Cristina Miranda Senna GOUVÊA ${ }^{1 *}$, Manuela Cristina Pessanha de ARAUJO², Daniel Filisberto SCHULZ \\ Sidney $\mathrm{PACHECO}^{2}$, Ronoel Luis de Oliveira GODOY², Lourdes Maria Corrêa CABRAL ${ }^{2}$
}

\begin{abstract}
Availability of analytical standards is a critical aspect in developing methods for quantitative analysis of anthocyanins. The anthocyanins cyanidin-3-O-glucoside and cyanidin-3-O-rutinoside were isolated from samples of freeze-dried açaí (Euterpe oleraceae Mart.), which is a round and purple well-known palm fruit in Brazil, and then used as standards. The isolation of the anthocyanins was performed by High Performance Liquid Chromatography (HPLC), using an adapted six-channel selection valve. The identification of anthocyanin pigments in açaí was based on mass spectrometric data for molecular ions and MS-MS product ions and on previous published data. After the collection procedure, standards with a high purity grade were obtained and an external standard curve of each anthocyanin was plotted.
\end{abstract}

Keywords: anthocyanins; standard; isolation; açaí; Euterpe oleraceae Mart.; HPLC.

\section{Resumo}

Disponibilidade de padrões analíticos é um aspecto crítico no desenvolvimento de métodos de análises quantitativas de antocianinas. Para a obtenção dos padrões isolados de antocianinas cianidina-3-O-glicosídeo e cianidina-3-O-rutinosídeo foram utilizadas amostras liofilizadas de açaí (Euterpe oleraceae Mart.), que é um conhecido fruto de palmeiras no Brasil de forma arredondada e roxo. O isolamento das antocianinas foi realizado por Cromatografia Líquida de Alta Eficiência (CLAE), utilizando uma válvula seletora de seis canais. A identificação de antocianinas no açaí foi baseada em dados publicados na literatura e por espectrometria de massas. Após a coleta, padrões com um alto grau de pureza foram obtidos e uma curva para padronização externa de cada antocianina foi feita.

Palavras-chave: antocianinas; padrões; isolamento; açaí; Euterpe oleracea Mart.; CLAE.

\section{Introduction}

Anthocyanins are mainly distributed among flowers, fruits, and vegetables and are responsible for most of the red, blue, and purple color (BROUILLARD, 1982; MALACRIDA; MOTTA, 2005). Recently, increased attention has been given to their possible health benefits in preventing chronic degenerative diseases including cancer and heart disease (DOWNHAM; COLLINS, 2000; MARTÍNEZ-FLÓREZ et al., 2002; KUSKOSKI et al., 2004; WALLE, 2004).

Measurement of anthocyanin content is critical for both research and industrial applications. Molar absorptivity in the solvent of choice is required for accurate measurement of anthocyanin content of identified pigments. To use the absorption coefficients, it is necessary to have the anthocyanins standards available. In spite of the large amounts of anthocyanins found in nature, not all of them are available on the market, and those that are commercialized are sold in small quantities with a low purity grade, besides being very expensive. The isolation of each anthocyanin is considered a problem mainly due to the difficulties of preparing crystalline anthocyanins, free from impurities, in sufficient amounts to allow reliable weighing under optimal conditions (GIUSTI; RODRÍGUEZ-SAONA; WROLSTAD, 1999). The availability of an efficient method for separation of anthocyanins, such as High Performance Liquid Chromatography (HPLC), combined with a list of absorption coefficients should simplify the quantitative estimation of individual anthocyanins (FRANCIS, 1989). A good source of anthocyanins and a practical method to collect them are also necessary to allow the isolation of those compounds in the laboratory.

Açaí is a fruit from typical Amazon palm tree Euterpe oleraceae Mart., which has a great content of anthocyanins, specially cyanidin-3-glucoside and cyanidin-3rutinoside (ARAUJO et al., 2008).

The objective of this research was to isolate anthocyanins analytical standards with high purity grade using an adapted fraction collector (Rheodyne ${ }^{\circledast}$ six-channel selection valve) in order to plot external standards curves using absorption and quantify other samples with cyanidin-3-glucoside and cyanidin3-rutinoside contents, thus solving the measurement problems previously mentioned.

\footnotetext{
Received $21 / 1 / 2010$

Accepted 15/11/2010 (004636)

1 Departamento de Ciência e Tecnologia de Alimentos, Universidade Federal Rural do Rio de Janeiro - UFRRJ, CEP 22793-810, Seropédica, RJ, Brazil,

e-mail: acristinagouvea@hotmail.com

2 Embrapa Agroindústria de Alimentos, Av. das Américas, 29501, CEP 23020-470, Guaratiba, Rio de Janeiro, RJ, Brazil

${ }^{3}$ Instituto de Química, Universidade Federal do Rio de Janeiro - UFRJ, CEP 21941-909, Rio de janeiro, RJ, Brazil

${ }^{*}$ Corresponding author
} 


\section{Material and methods}

\subsection{Solvents}

High-Performance Liquid Chromatography (HPLC) grade formic acid and methanol were purchased from Tedia (USA). Ultrapure water was obtained from Milli-Q Gradient 10A System.

\subsection{Sample}

The freeze-dried açaí was supplied by Embrapa CPATU at Belém, PA, Brazil and was stored at $-18{ }^{\circ} \mathrm{C}$ until extraction and analysis.

\subsection{Sample preparation}

The sample extraction method used was described in a previous published study (BRITO et al., 2007) with the following modifications: $1 \mathrm{~g}$ of freeze-dried fruit and extract concentration on rotary evaporator at $38^{\circ} \mathrm{C}$ before its evaporation under $\mathrm{N}_{2}$ flow.

\subsection{HPLC conditions}

Chromatography was performed on a Waters ${ }^{\circledR}$ Alliance 2695 system equipped with a Waters 2996 photodiode array detector (at $520 \mathrm{~nm}$ ) and a Rheodyne six-channel selection valve. This valve is actually a device that allows the use of different columns in the same chromatography analysis, and it is connected at the injector exit and was used as collecting device. The column used was a Symmetry ${ }^{\oplus} \mathrm{C}_{18}(150 \mathrm{~mm} \times 4.6 ; 3.5 \mu \mathrm{m})$. The mobile phase consisted of $10 \%$ aqueous formic acid (solvent A) and methanol (solvent $\mathrm{B}$ ). The selecting valve was programmed to switch to channel one at the beginning of the cyanidin-3-O-glucoside elution (at 16.2 minutes) and switch back to discharge position after its partial elution (at 18.4 minutes). The same procedure was done with cyanidin-3-O-rutenoside, but at this time the selecting valve was programmed to switch to channel two at 21.4 minutes and switch back to discharge position at 22.9 minutes. The collection procedure was performed with 30 injections of the extract.

\subsection{Standard concentration}

The collected standards were concentrated through Waters ${ }^{\circ}$ Sep-Pak C18 cartridges, where they were eluted with methanol. Aliquots of the isolated standards were injected under the same chromatographic conditions described before, and therefore, it was possible to verify their purity grades by the peaks areas.

\subsection{ESI-MS conditions}

Identification was performed on a Waters ${ }^{\circledR}$ Synapt mass spectrometer system with a syringe pump. This system is equipped with the high resolution analyzers QTOF. The MS source used was positive ion electrospray (ESI), and the following conditions were used: source temperature at $80^{\circ} \mathrm{C}$, drying gas $\left(\mathrm{N}_{2}\right)$ delivered at $5 \mathrm{~L} / \mathrm{min}$ at $150^{\circ} \mathrm{C}$, capillary exit set at $3 \mathrm{kV}$, sampling cone set at $35 \mathrm{~V}$, and extraction cone set at $4 \mathrm{~V}$.

The quantification of each isolated standard was performed on a Shimadzu UV1800 spectrophotometer using the BeerLambert Law $(A=\varepsilon . b . c)$, at $520 \mathrm{~nm}$. $100 \mu \mathrm{L}$ of each concentrated standard were dried under $\mathrm{N}_{2}$ flow and ressuspended in $2 \mathrm{~mL}$ of a solution, in which the molar absorptivity in the used solvent is known for each anthocyanin. For the cyanidin-3-O-glucoside, the molar absorptivity is known for the solution $1 \% \mathrm{HCl}$ in methanol $\left(\varepsilon=34300 \mathrm{~L} \cdot \mathrm{mol}^{-1} \cdot \mathrm{cm}^{-1}\right)$, and for the cyanidin3 -rutinoside, it is known for the solution $1 \% \mathrm{HCl}$ in water $\left(\varepsilon=28840 \mathrm{~L} \cdot \mathrm{mol}^{-1} \cdot \mathrm{cm}^{-1}\right)$ (GIUSTI, RODRÍGUEZ-SAONA, WROLSTAD, 1999; BRITO et al., 2007; COHEN, ALVES, 2006). From each standard solution with known concentrations, 8 dilutions were done, and the anthocyanins external standard curves were plotted.

\section{Results and discussion}

The HPLC chromatogram obtained from freeze-dried açaí shows peaks with good resolution and magnitude (Figure 1 and Table 1) allowing the isolation of each anthocyanin by the collection of the respective peaks using an adapted Rheodyne ${ }^{\circ}$ six-channel selection valve connected to the HPLC system.

The isolated anthocyanins (Figure 2 and 3) showed a high purity grade: cyanidin-3-glucoside $=98.9 \%$ and cyanidin- 3 rutinoside $=97.2 \%$. The procedure adopted during the standard collection changing back the selecting valve to the discharge

Table 1. Identification of anthocyanins in açaí.

\begin{tabular}{ccc}
\hline Peak & Anthocyanin & Retention time (minute) \\
\hline 1 & cyanidin-3-glucoside & 17.8 \\
2 & cyanidin-3-rutinoside & 22.2 \\
\hline
\end{tabular}

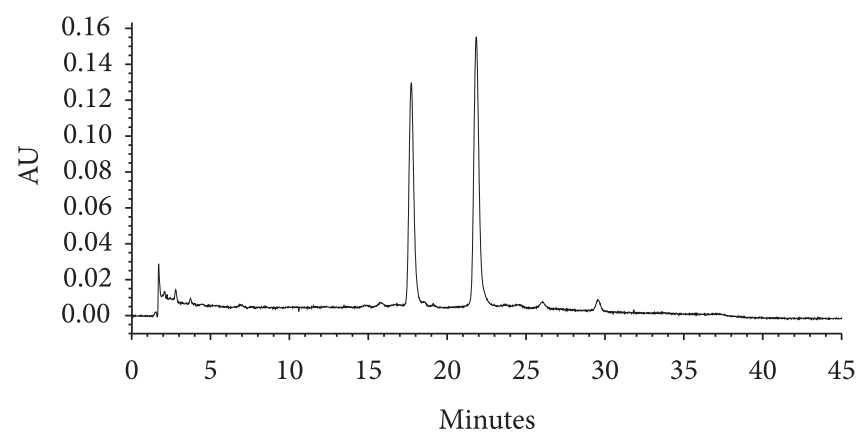

Figure 1. HPLC chromatogram of anthocyanin profile for açaí.

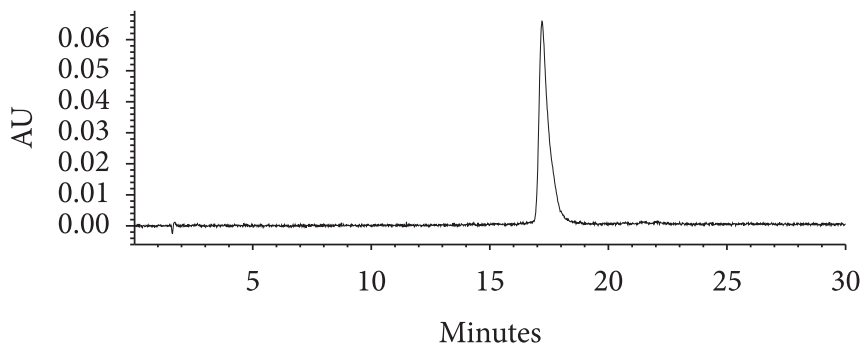

Figure 2. HPLC chromatogram of isolated cyanidin-3-O-glucoside.

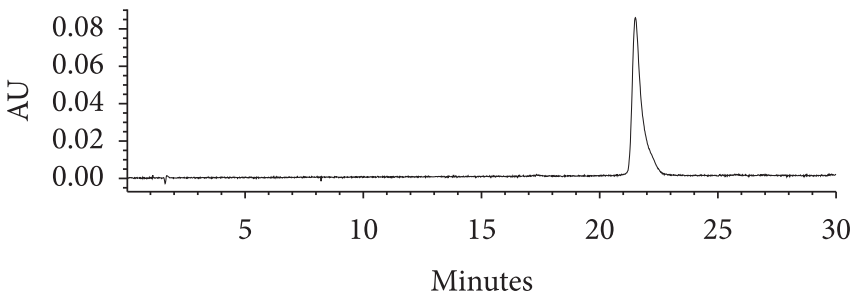

Figure 3. HPLC chromatogram of isolated cyanidin-3-O-rutinoside. 
position after partial elution, allowed the anthocyanin collection without interference. The external standard curves plotted for each one of the two anthocyanins had a good squared correlation coefficient $\left(\mathrm{r}^{2}\right)$ : cyanidin-3-glucoside $=0.999658$ and cyanidin3-rutinoside $=0.999687$ (Figure 4 and 5). the anthocyanins contents of an extract obtained from the same freeze-dried açaí sample, following a method used before (BRITO et al., 2007), were determined from these curves (Table 2).

There are studies, in which the content of anthocyanins is estimated by the $\mathrm{pH}$-differential method. Although it is a practical and not expensive method, it does not allow the quantification of isolated anthocyanins. Its results relate the total anthocyanins content, generally expressed in cyanidin-3-O-glucoside equivalent. In addition, there is a lack of uniformity in the values of absorptivity reported for this method, which can result in wrong content calculation (WROLSTAD; DURST; LEE, 2005).
As show in Table 3, the molecular ion and its fragments were used to confirm the identity of the anthocyanins isolated. The first anthocyanin isolated, retention time 17.8 minutes, showed a molecular ion $\mathrm{m} / \mathrm{z} 449$, suggesting the presence of cyanidin-3-O-glucoside, which was confirmed by the fragment ion $\mathrm{m} / \mathrm{z} 287$, which corresponds to aglycone cyanidin (Figure 6).

Table 2. Quantification of anthocyanins in freeze-dried açaí.

\begin{tabular}{cc}
\hline Anthocyanin & $\mathrm{mg} .100 \mathrm{~g}^{-1}$ \\
\hline cyanidin-3-glucoside & $35.29 \pm 0.12$ \\
cyanidin-3-rutinoside & $58.73 \pm 0.22$ \\
\hline
\end{tabular}

Table 3. Identification of anthocyanins isolated from freeze-dried açaí.

\begin{tabular}{ccc}
\hline Peak & {$[\mathrm{M}]^{+}(m / z)$} & MS-MS $(m / z)$ \\
\hline 1 & 449 & 287 \\
2 & 595 & $449 / 287$ \\
\hline
\end{tabular}

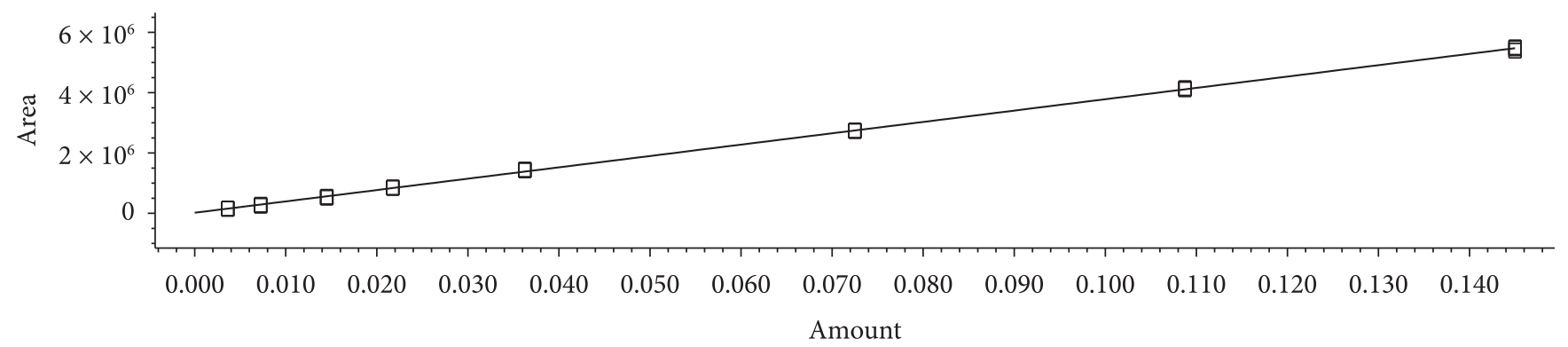

Figure 4. External standard curve of isolated cyanidin-3-O-glucoside $\left(\mathrm{Y}=4.03 \times 10^{7} \mathrm{X}+2.81 \times 10^{4}\right)$.

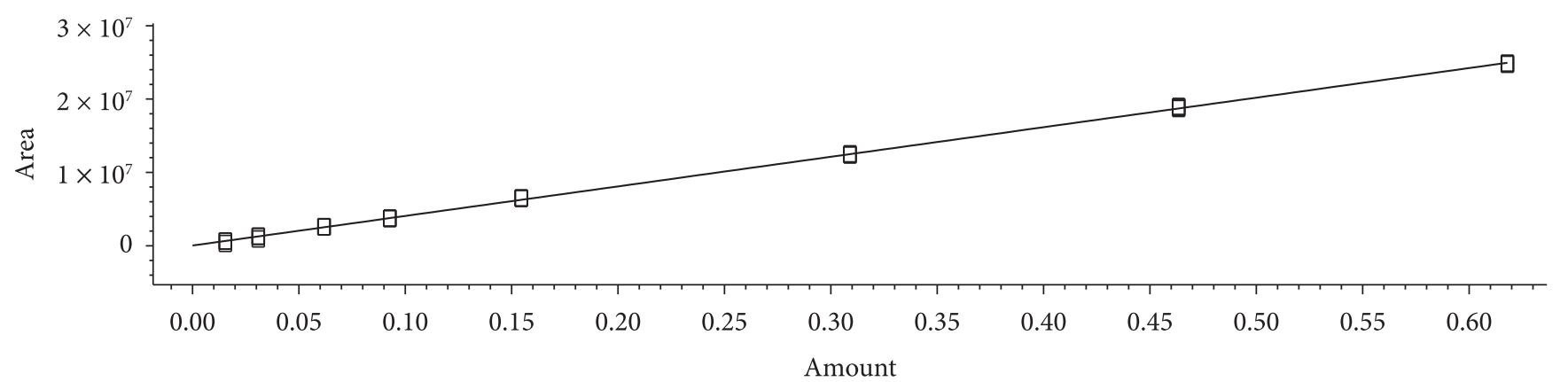

Figure 5. External standard curve of isolated cyanidin-3-O-rutinoside $\left(\mathrm{Y}=3.76 \times 10^{7} \mathrm{X}+1.75 \times 10^{4}\right)$.

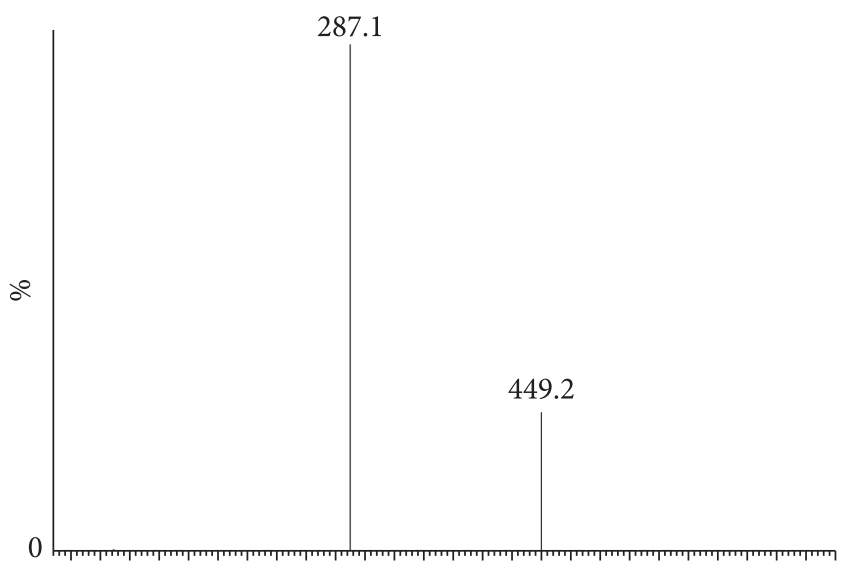

50100150200250300350400450500550600650700 $\mathrm{m} / \mathrm{z}$

Figure 6. MS-MS spectra of cianydin-3-O-glucoside.

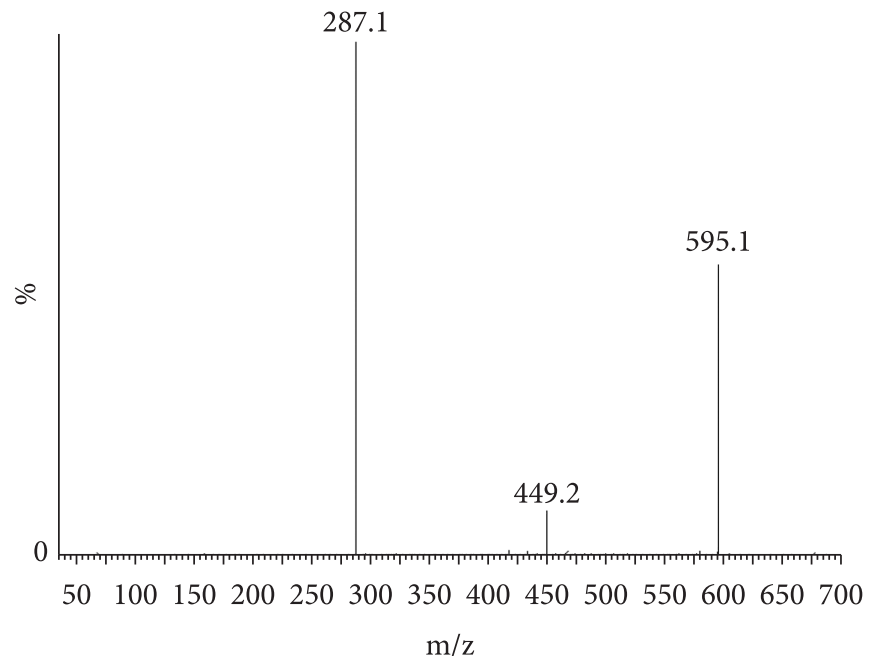

Figure 7. MS-MS spectra of cianydin-3-O-rutinoside. 
The second anthocyanin isolated, retention time 22.2 minutes, showed a molecular ion at $\mathrm{m} / \mathrm{z} 595$ suggesting the presence of cyanidin-3-O-rutinoside. The ion of $\mathrm{m} / \mathrm{z} 449$ showed the loss of one molecule of rhamnoside and ion of $\mathrm{m} / \mathrm{z} 287$ confirmed the presence of aglycone cyanidin (Figure 7).

\section{Conclusion}

The selection valve adapted as a fraction collector can be considered a successful innovation since it was possible to isolate the analytical standards.

This practical and reliable method can be used to isolate other anthocyanins from different samples thus allowing the characterization of more fruits and vegetables.

\section{References}

ARAUJO, M. C. P. et al. Adaptação de um método por Cromatografia Líquida de Alta Eficiência para determinação de antocianinas em suco de açaí (Euterpe oleraceae Mart.). In: CONGRESSO LATINO AMERICANO DE CROMATOGRAFIA E TÉCNICAS AFINS, 12., 2008, Florianópolis. Anais... Florianópolis, 2008.

BRITO, E. S. et al. Anthocyanins present in selected tropical fruits: acerola, jambolão, jussara, and guajiru. Journal of Agricultural and Food Chemistry, v. 55, p. 9389-9394, 2007.

BROUILLARD, R. Chemical structure of anthocyanins. In: MARKAKIS, P. (Ed.). Anthocyanins as Food Colors. New York: Academic Press, 1982. p. 1-40.

COHEN, K. O.; AlveS, S. M. Açaí. Embrapa Amazônia Oriental, 2006. Sistemas de Produção, v. 4. Disponível em: <http:// sistemasdeproducao.cnptia.embrapa.br/FontesHTML/Acai/ SistemaProducaoAcai_2ed/index.htm>. Acesso em: 12 fev. 2008.
DOWNHAM, A.; COLLINS, P. Colouring our foods in the last and next millennium. International Journal of Food Science \& Technology, v. 35, n. 1, p. 5-22, 2000. PMid:21848869. http://dx.doi. org/10.1046/j.1365-2621.2000.00373.x

FRANCIS, F. J. Food Colorants: anthocyanins, Crit. Rev. Food Science Nutrition, v. 28, n. 4, p. 273-314, 1989. PMid:2690857. http://dx.doi. org/10.1080/10408398909527503

GIUSTI, M. M.; RODRÍGUEZ-SAONA, L. E.; WROLSTAD, R. E. Molar absorptivity and Color characteristics of Acylated and nonAcylated Pelargonidin-Based Anthocyanins. Journal Agriculture Food Chemistry, v. 47, p. 4631-4637, 1999. PMid:10552862. http:// dx.doi.org/10.1021/jf981271k

KUSKOSKI, E. M. et al. Actividad antioxidante de pigmentos antociánicos. Ciência e Tecnologia de Alimentos, v. 24, n. 4, p. 691-693, 2004. http://dx.doi.org/10.1590/S010120612004000400036

MALACRIDA, R. C.; MOTTA, S. Compostos fenólicos totais e antocianinas em suco de uva. Ciência e Tecnologia de Alimentos, v. 25 , n. 4 , p. $659-664,2005$. http://dx.doi.org/10.1590/S010120612005000400006

MARTÍNEZ-FLÓREZ, S. et al. Los flavonóides: propriedades y acciones antioxidantes. Nutritión Hospitalaria, v. 17, n. 6, p. 271-278, 2002. PMid:12514919.

WALLE, T. Serial review: flavonoids and isoflavones (phytoestrogens): absorption, metabolism, and bioactivity. Free Radical Biology \& Medicine, v. 36, n. 7, p. 829-837, 2004. PMid:15019968. http:// dx.doi.org/10.1016/j.freeradbiomed.2004.01.002

WROLSTAD, R. E.; DURST, R. W.; LEE, J. Tracking color and pigments changes in anthocyanins products. Trends in Food Science and Technology, v. 16, p. 423, 2005. PMid:21299575. http://dx.doi. org/10.1016/j.tifs.2005.03.019 